\title{
In Vitro Regeneration and Ex Vitro Establishment of an Antidiabetic Plant- Gynura procumbens (Lour.) Merr.
}

\author{
Mustafa AbulKalam Azad, Muhammad Nurul Amin \\ Department of Botany, University of Rajshahi, Rajshahi 6205, Bangladesh \\ *Corresponding Author: Dr. Mustafa AbulKalam Azad, Associate Professor, Department of Botany, \\ University of Rajshahi, Rajshahi 6205, Bangladesh.E-mail: drmakazad@gmail.com

\begin{abstract}
A most effective protocol for axillary shoot proliferation was established on MS medium supplemented with different concentrations of cytokinin and auxin using nodal and shoot tip explants from field grown mature plant of Gynura porcambens. In vitro response of the explants to multiple shoot regeneration varied greatly with the position of the explanting branch on the donor plant. Highest frequency 98.21\% of shoot formation, maximum number 6.2 of shoots per explant and average $4.5 \mathrm{~cm}$ length of shoot were obtained on MS medium supplemented with $4.0 \mu$ M 6-Benzylaminopurine (BAP). Shoot multiplication and growth were significantly affected by level of concentration of sucrose. Optimum sucrose concentration was also estimated for in vitro shoot regeneration from nodal explant in MS medium with different concentrations of sucrose. The highest rate (97.31\%) of shoot production was achieved in a shootregenerating medium with $30 \mathrm{gm} / \mathrm{l}$ sucrose. For rooting, the in vitro proliferated and elongated shoots were excised into 2-4 cm long microcuttings, which were planted individually on a root-induction MS medium containing 4.0 $\mu \mathrm{M}$ Indole-3-butyric acid (IBA). Within 4 weeks of transfer to the rooting medium, all the cultured microcuttings produced 2-6 roots. The in vitro regenerated plantlets were transferred to soil, and the survival rate ex vitro was $95.00 \%$.
\end{abstract}

Keywords: Medicinal Plant, Nodal Segments, Plant Growth Regulators, Sucrose.

\section{INTRODUCTION}

Gynura procumbens Merr. belonging to the family Asteraceae is a medicinal plant commonly found in tropical Asia countries such as China, Thailand, Indonesia, Malaysia, and Vietnam. Traditionally, it is widely used in many different countries for the treatment of a wide variety of health ailments such as kidney discomfort, rheumatism, diabetes mellitus, constipation, and hypertension. Based on the traditional uses of $G$. procumbens, it seems to possess high therapeutic potential for treatment of various diseases making it a target for pharmacological studies aiming to validate and provide scientific evidence for the traditional claims of its efficacy. Recently, pharmacologic studies reported that $G$. procumbens has anti-Herpes simplex virus, anti-hyperglycemic, anti-hyperlipidemic, antiinflammatory, analgesic, and reduced blood hypertension properties (Lam et al., 1998; Akowuahet al., 2001, 2002; Iskanderet al., 2004).

This plant is conventionally propagated by stem cuttings. The conventional method cannot meet the increasing demandof this plant used as the raw material for the preparation of pharmaceutical, dermaceutical and aromatherapeutical products. The in vitro culture techniques can be the alternative for the continuous provision of plantlet stocks for large scale field cultivation. More and more medicinal plant species are now propagated via in vitro culture techniques, just to mention a few, such 

Merr.

as Centellaasiatica (Tiwari et al., 2000), Vitisthunbergii (Mei, 2005) and even woody medicinal plant, Garcinia indica (Malik et al., 2005), Phellodendronamurense (Azad et al.,2012 ) also.

By considering the medicinal value and antidiabetic properties of G. procumbens the present project has been undertaken for develop a suitable micropropagation protocol for the mass production of this plant species. Here, we will try to establish an efficient protocol which can be used at a large scale for the clonal multiplication of this plant species using nodal segments as explants derived from the adult plants and will be followed by the optimized conditions for in vitro rooting and further transfer into the greenhouse. To our knowledge, there are few reports on micropropagation of this plant species.

\section{MAterials AND Methods}

Nodal and shoot tip explants of Gynura procambens were collected from a medicinal plant garden in Rajshahi University campus, Bangladesh. Explants were washed thoroughly under running tap water for 15 minutes and then washed with continuous agitation in a few drops Savlon containing water for 15 minutes. The washed explants were then treated with $0.1 \% \mathrm{HgCl}_{2}$ for 10 minutes under laminar air flow cabinet to disinfect them. Finally, explants were washed 3 to 5 times with sterile distilled water and were placed in culture tubes $(25 \times 150 \mathrm{~mm})$ containing $4.0 \mu \mathrm{M}$ BAP supplemented MS (Murashige and Skoog, 1962) medium prepared with 3\% (w/v) sucrose and 0.8\% (w/v) agar (Sigma Chemical Co. USA). The $\mathrm{pH}$ of the medium was adjusted to $5.7 \pm 1$ before autoclaving at $121^{\circ} \mathrm{C}$ for 20 minutes at $1.2 \mathrm{~kg} / \mathrm{cm}^{2}$ pressure.

To test the effect of basal medium on in vitro shoot multiplication, nodal explants were initially cultured on four different basal medium viz. MS (Full strength of MS medium), MMS1 (Half strength of MS medium), MMS2 (Quarter strength of MS medium) and B5 (Gamborgedet al., 1968) supplemented with $4.0 \mu \mathrm{M}$ BAP. In addition, excised nodes of in vitro grown shoots were cultured on MS medium containing various concentrations $(2.0-6.0 \mu \mathrm{M})$ of BAPalone or in combination of 1.0 $\mu \mathrm{M}$ of IBA (Indole-3-butyric acid) orNAA (1-Napthaleneacetic acid) to test their shoot induction efficiency. Nodal explants were also used for examining the effects of the sucrose concentrations on shoot regeneration. Four different concentrations (10.0, 20.0, 30.0 and $40.0 \mathrm{gm} / \mathrm{l})$ of sucrose in a medium were employed for the experiments. Microshoots of 1-3 cm length were prepared from usable shoots by snipping off the basal leaves and cultured them individually in $25 \times 150 \mathrm{~mm}$ culture tubes with $10-15 \mathrm{ml}$ of full strength MS medium supplemented with2.0-6.0 $\mu \mathrm{M}$ of IBA,NAA, or IAA (Indole-3-acetic Acid)

The rooted plantlets were transferred on to the small plastic pots containing sterilized soil mix (garden soil: sand: compost in 2:1:1 ratio). Transferred plantlets were hardened in growth chamber condition for 20 days and then transferred to outdoor condition. The total number of plants transferred to the pots and the number of surviving plants in the outdoor condition were recorded. All the cultures were maintained at $25 \pm 1{ }^{\circ} \mathrm{C}$ under a $16 \mathrm{~h}$ light and $8 \mathrm{~h}$ dark cycle with the light intensity of 2000-3000 lux provided by cool-white fluorescent tubes $(36 \mathrm{~W})$. Data were recorded after 8 weeks of culture except for rooting experiment when the data were recorded after 4 weeks of incubation. In all the experiments, 12-15 explants were used and each experiment was repeated three times. Mean and standard error were calculated for all numerical data. The mean data of each treatment were compared by using Duncan's Multiple Range Test (DMRT) at $\mathrm{P}=0.05 \%$.

\section{RESULTS AND DISCUSSION}

Nodal explants showed the best shoot proliferation efficiency irrespective of media type, which followed by shoot tip explants (Fig. 1). Nodal explants showed the maximum $98.21 \pm 1.01 \%$ response and produced $6.22 \pm 0.51$ shoots and average length of shoots $4.51 \pm 0.24 \mathrm{~cm}$ on MS medium with 4.0 $\mu \mathrm{M}$ BAP while the shoot tips formed maximum $3.11 \pm 0.62$ shoots, and $3.24 \pm 0.71 \mathrm{~cm}$ shoot length, 

Merr.

respectively on the same media formulation (Fig. 2A-B). Results of this experiment indicated the high regenerative capacity of nodalexplants of $G$. procambens than shoot tip explants. On the other hand Parvinet al. (2014) reported that shoot tip explant was superior to nodal explant for multiple shoot induction. Our findings were similar to the medicinal species, such as G. porcambens (Alizah and Nurulaishah, 2014, Kenget al., 2009; Majumderet al., 2016); Phaleriamacrocarpa (Abdullah et al., 2014);Medinillamandrakensis (Elinorovololona and Martial, 2014), Phellodendronamurense (Azad et al., 2005); Adhatodavaisca (Azad et al., 2003) and Ocimumbacilicum (Begum et al., 2002).

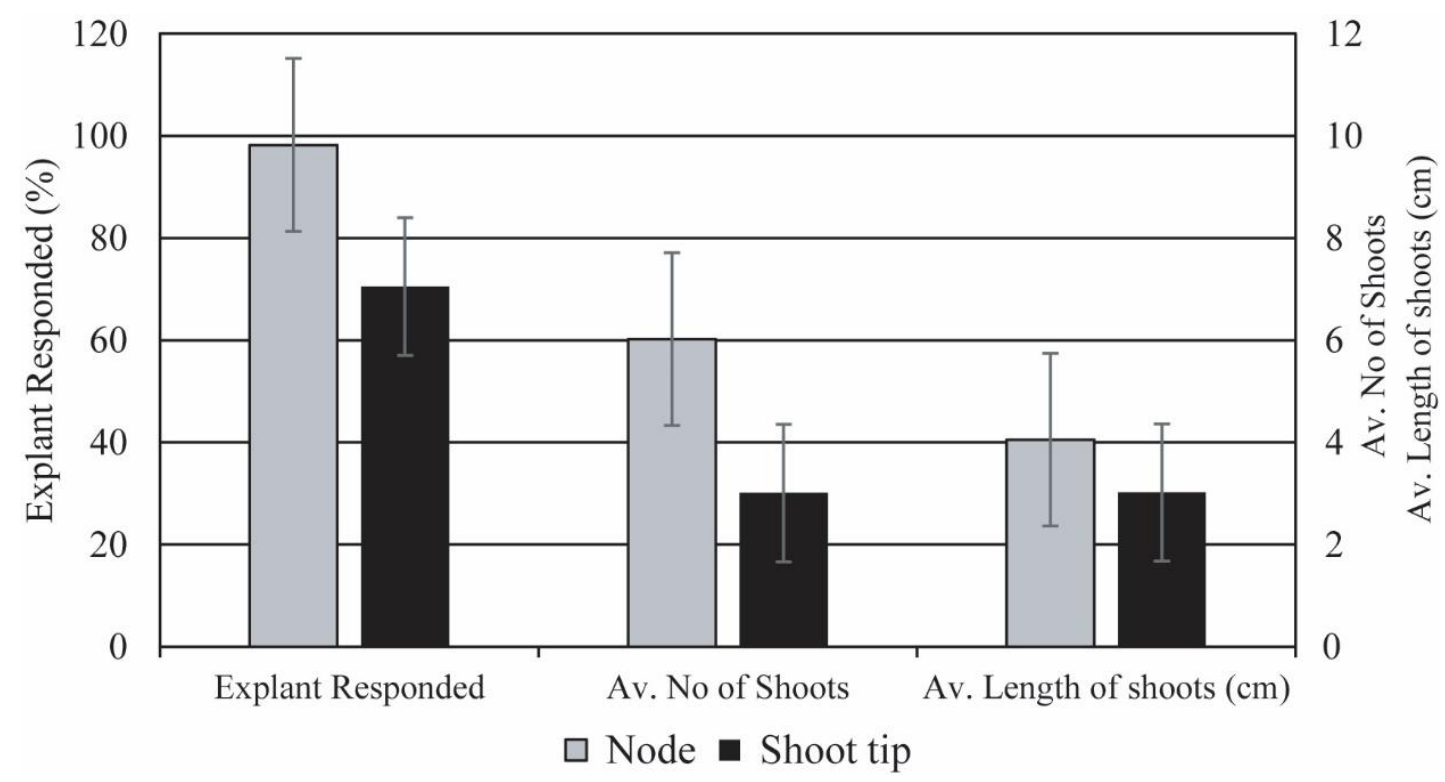

Figure 1. Effects of explants on MS medium containing 4.0 $\mu M$ BAP on axillary shoot proliferation of Gynura porcambens.

The nodal explants significantly affectedshoot proliferation on full strength MS medium supplement with 4.0 $\mu \mathrm{M}$ BAP than other three media (MMS1, MMS2 and B5) tested (Fig. 3). Maximum 98.52 \pm $1.51 \%$ explants produced highest $6.53 \pm 0.61$ shoots with highest average length $4.33 \pm 0.41 \mathrm{~cm}$ on MS medium. The second highest frequency $95.05 \%$ of shoot proliferation $6.11 \pm 0.31$ average number of shoot and $3.81 \pm 0.42 \mathrm{~cm}$ length of shoot were obtained on MMS1 medium. Considerable shoot proliferation were observed on B5 medium. The lowest performance of shoot proliferation, number of shoot, and shoot length were found on MMS2 medium. This study revealed that full strength MS medium was preferred for axillary shoot proliferation from nodal explants of G. procambens while B5 medium showed a little effect in terms of shoot proliferation. Full strength MS medium has been proved best for axillary shoot proliferation in many other medicinal species, such as Phaleriamacrocarpa (Abdullah et al., 2014); G. porcambens (Alizah and Nurulaishah, 2015, Kenget al., 2009; Majumderet al., 2016); Adhatodavasica (Azad et al., 2003); Ocimum sanctum (Begum et al., 2000); andRauvolfiaserpentia (Shahrearet al., 2002).Similar results were also observed in some other woody trees, like Phellodendronamurense (Azad et al., 2004), Accia catechu (Kaur et al., 1998), Accianilotica (Abbas et al., 2010), Coluteaistria (Hegazi and Gabr, 2010), Pterocarpus marsupium (Hussain et al., 2008), P. santalinus (Rajeswari and Paliwal, 2008), Sterculiaurens (Hussain et al., 2007) andLagerstromiaparviflora (Tiwari et al., 2002).

Results influenced on the various concentrations of BAP alone or in combination with IBA or NAA in axillary shoot proliferation from nodal explants are given in Table 1. Nodal explants also cultured on MS medium devoid of growth regulator produced $1.2 \pm 0.1$ shoots, $1.4 \pm 0.2 \mathrm{~cm}$ lengths with $50.12 \%$ shoot regeneration frequency, which may be due to the presence of endogenous cytokinin in nodal 

Merr.

explant, suggested by Rajeswari and Paliwal (2008) in Pterocarpussantalinus. However, the addition of exogenous cytokinin to MS medium induced shoot multiplication rate remarkably, indicating the requirement of exogenous cytokinin supply in the medium for better axillary shoot proliferation. Among the various concentrations $(2.0-6.0 \mu \mathrm{M})$ of BAP the highest frequency $91.33 \%$ of shoot proliferation, $6.1 \pm 0.4$ number of shoots and $4.5 \pm 0.2 \mathrm{~cm}$ shoot length were observed when nodal cultured on MS medium supplemented 4.0 $\mu \mathrm{M}$ BAP alone. These results indicated that BAP, a cytokinin, played an important role in induction of multiple shoot formation and was very effective in shoot proliferation. However, BAP at higher concentrations not only reduced the number of shoots formed but also resulted in stunted growth of the shoots. Similar synergistic effects were demonstrated in G. porcambens (Alizah and Nurulaishah, 2014; Kenget al., 2009) and Phaleriamacrocarpa (Abdullah et al., 2014).

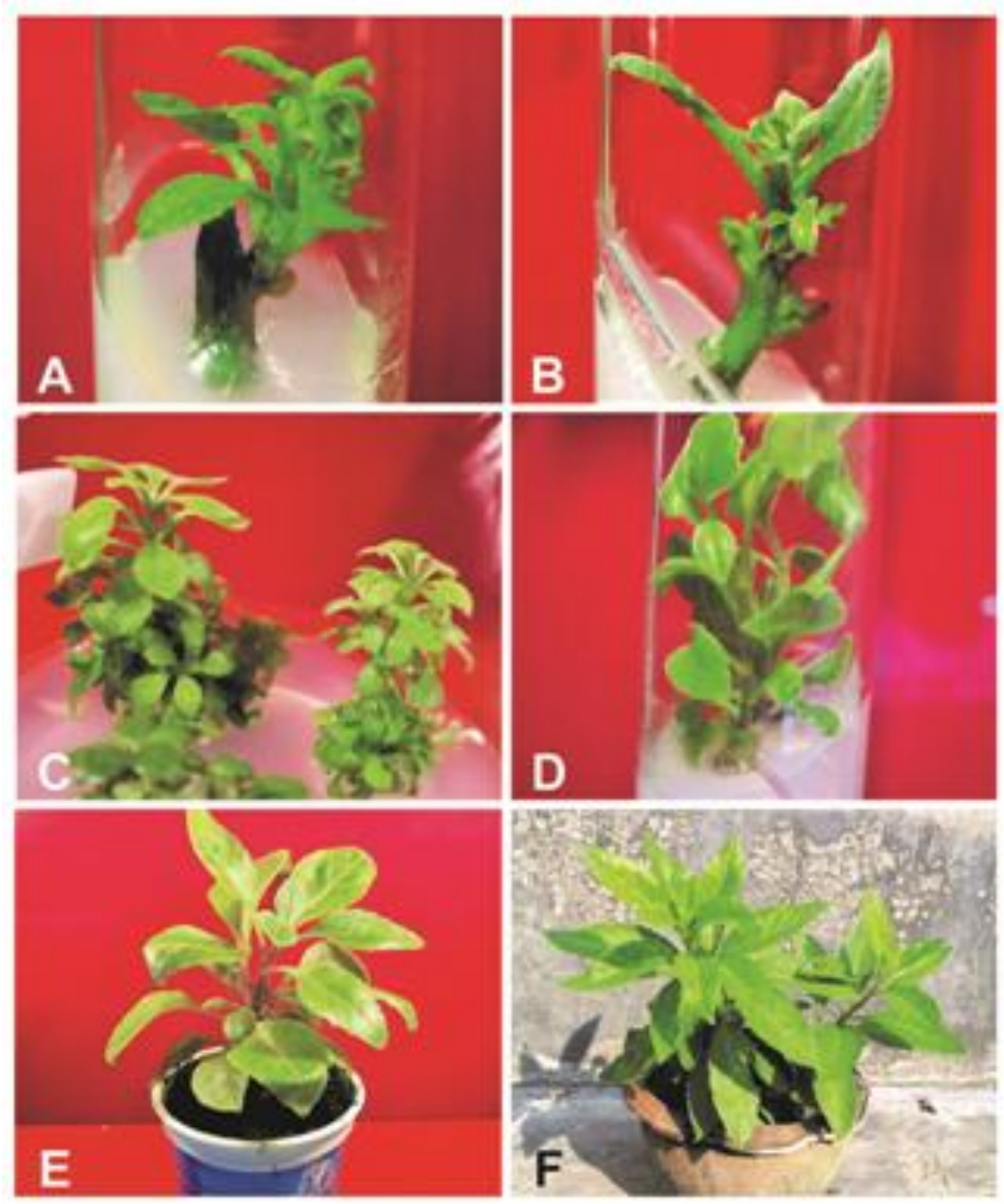

Figure 2. A-E: In vitro regeneration of plantlet from node and shoot tip explants of Gynura porcambens.

A-B: Proliferation of axillary shoots from node (A) and shoot tip (B) explants cultured on MS medium supplemented with $4.0 \mu \mathrm{M}$ BAP after four weeks of culture.

C: Proliferation and development of multiple shoots from nodal segments on MS medium containing $4.0 \mu \mathrm{M}$ BAP plus $1.0 \mu \mathrm{M}$ IBA after eight weeks of culture.

D: Formation of roots from the regenerated shoots cultured on MS medium supplemented with 4.0 $\mu \mathrm{M} \mathrm{IBA}$.

E-F: Growth of transplant on the soil after eight weeks (E) and twelve weeks (F) of transfer under ex vitroconditions. 
In Vitro Regeneration and Ex Vitro Establishment of an Antidiabetic Plant- Gynura procumbens (Lour.) Merr.

Table1. Effects of plant growth regulators on axillary shoot proliferation from nodal explants of Gynura porcambens.

\begin{tabular}{|c|c|c|c|}
\hline $\begin{array}{l}\text { Plant Growth Regulators } \\
(\mu \mathrm{M})\end{array}$ & Explant responded (\%) & Av. No of shoots & $\begin{array}{l}\text { Av. Length of shoots } \\
(\mathrm{cm})\end{array}$ \\
\hline Control (HO) & $50.12 \pm 1.3 d$ & $1.2 \pm 0.1 \mathrm{f}$ & $1.4 \pm 0.2 \mathrm{e}$ \\
\hline \multicolumn{4}{|l|}{ BAP } \\
\hline 2.0 & $70.59 \pm 1.5 c$ & $3.6 \pm 0.9 \mathrm{~d}$ & $3.9 \pm 0.1 b$ \\
\hline 4.0 & $91.33 \pm 1.9 \mathrm{a}$ & $6.1 \pm 0.4 a$ & $4.5 \pm 0.2 \mathrm{a}$ \\
\hline 6.0 & $82.37 \pm 1.4 b$ & $4.3 \pm 0.7 c$ & $4.1 \pm 0.5 b$ \\
\hline \multicolumn{4}{|l|}{$\mathrm{BAP}+\mathrm{IBA}$} \\
\hline $2.0+1.0$ & $72.81 \pm 1.7 \mathrm{c}$ & $3.1 \pm 0.6 \mathrm{~d}$ & $3.1 \pm 0.8 \mathrm{c}$ \\
\hline $4.0+1.0$ & $86.39 \pm 1.5 b$ & $4.9 \pm 0.4 b$ & $4.2 \pm 0.6 \mathrm{ab}$ \\
\hline $6.0+1.0$ & $77.87 \pm 1.3 c$ & $3.5 \pm 0.9 \mathrm{~d}$ & $3.5 \pm 0.4 \mathrm{a}$ \\
\hline \multicolumn{4}{|l|}{$\mathrm{BAP}+\mathrm{NAA}$} \\
\hline $2.0+1.0$ & $69.52 \pm 1.6 c$ & $2.1 \pm 0.7 \mathrm{e}$ & $2.5 \pm 0.6 \mathrm{~d}$ \\
\hline $4.0+1.0$ & $83.67 \pm 1.4 b$ & $4.1 \pm 0.6 c$ & $3.8 \pm 0.3 b$ \\
\hline $6.0+1.0$ & $75.33 \pm 1.7 \mathrm{c}$ & $2.5 \pm 0.9 \mathrm{e}$ & $2.9 \pm 0.4 c$ \\
\hline
\end{tabular}

Values represent means \pm standard error of 12-15 explants per treatment in four repeated experiments. Means followed by the same letter are not significantly diff erent by the Tukey's multiple comparison test at 0.05 probability level.

BAP and IBA, BAP and NAA combinations also affected normal growth and proliferation of axillary shoots. The maximum of $86.39 \%$ explants produced normal shoots with $4.9 \pm 0.4$ shoots and $4.2 \pm 0.6$ $\mathrm{cm}$ shoot length when they were cultured with $4.0 \mu \mathrm{M}$ BAP and 1.0 $\mu \mathrm{M}$ IBA (Fig. 2C). Other combinations of BAP and IBA in the initial media greatly altered the growth behaviour of the cultured explants that proliferated axillary shoots. BAP-NAA combination was also produced better result for shoot proliferation. In this formulation, MS medium supplemented with 4.0 $\mu \mathrm{MBAP}$ and $1.0 \mu \mathrm{MNAA}$ was found to be the effective medium for shoot proliferation resulting in the formation of an average of $4.1 \pm 0.6$ shoots per explant and average shoot length $3.8 \pm 0.3 \mathrm{~cm}$. This is in agreement with the result of G. porcambens (Kenget al., 2009), Santolinacanescens (Casadoet al., 2002), and Rotulaaquatica (Martin, 2003). Our results showed that BAP is very effective in induction of multiple shoot from nodal segment. BAP is regarded the most effective cytokinin for shoot induction and is widely used in in vitro propagation of plants. The enhanced rate of multiple shoot induction in cultures supplemented with BAP may be largely ascribed due to increased rates of cell division induced by cytokinin (BAP) in the terminal and axillary meristematic zone of explant tissues. Cells in this zone divide with the faster pace and thus, produced large number of shoots (Niranjanet al., 2010).

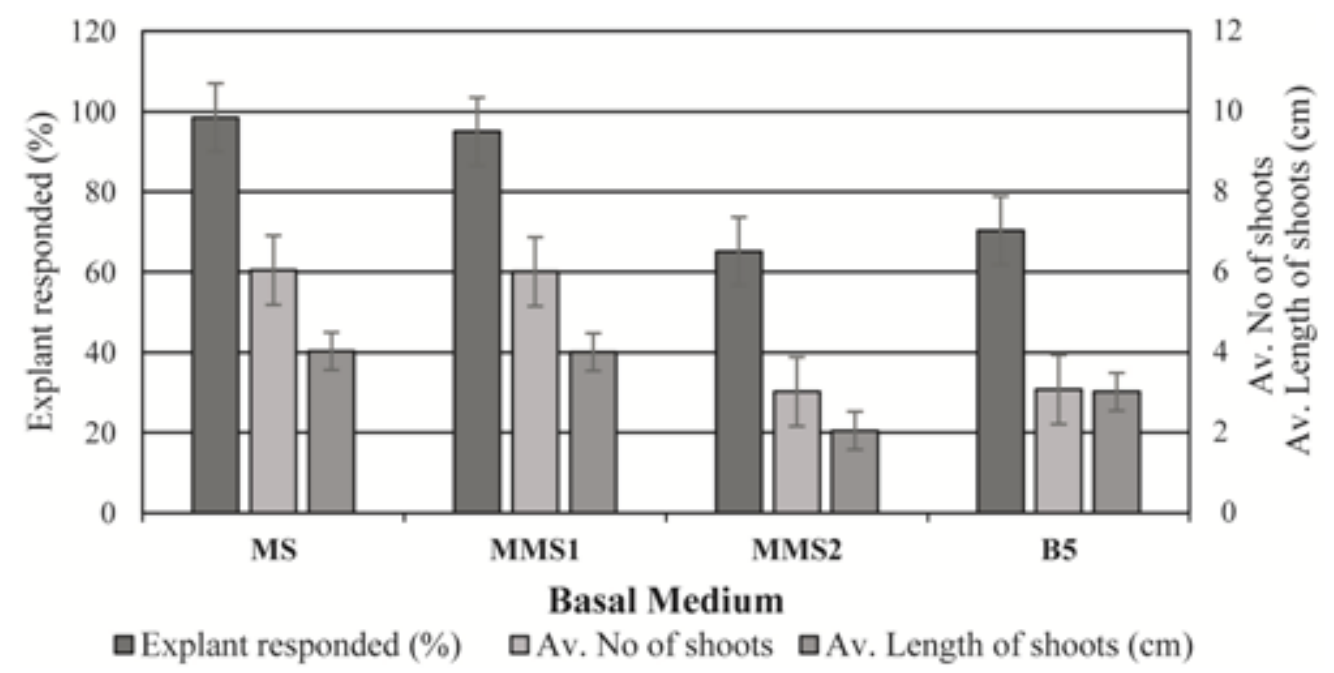

Figure 3. Effects of different basal media containing $4.0 \mu M$ BAP on in vitro shoot multiplication from nodal explants of Gynura porcambens. 

Merr.

Shoot development from nodal explant may vary among species and genotypes upon the level of optimum sucrose concentration (Nowak et al., 2004). The percentage of shoot formation, total number of shoots per culture and average length of shoots per culture increase gradually with the increase of the sucrose concentration in medium up to $30 \mathrm{gm} / \mathrm{l}$. However, the performance of shoot development gradually decreased with an increase in the sucrose concentration to above $30 \mathrm{gm} / \mathrm{l}$. The medium with $30 \mathrm{gm} / 1$ sucrose showed the highest percentage of shoot formation (97.3\%), total number of shoots per culture (6.4 \pm 0.3$)$ and average length of shoots per culture $(4.9 \pm 0.4 \mathrm{~cm})$ (Fig. 4). Anefficient carbon sources for enhanced shoot growth and development has been examined in tissue culturesof some plant species, such as Echinacea purpurea (Nilanthai and Yang, 2013), Allium chinense (Zuet al., 2008), Elaeocarpusrobustus (Rahman et al., 2004) and Paederiafoetida (Amin et al., 2003).Our study revealed that MS medium with $30 \mathrm{gm} / 1$ sucrose showed the best result for shoot formation in $G$. porcambens. Lower concentrations of sucrose have been shown to be less effective for shoot formation. On the other hand, the detrimental effect of a high sucrose concentration on shoot formation implies that the osmotic level in themedium may be inhibitory to further shoot development. Thus, high concentrations of sucrose seem to inhibit shoot growth and development. This observation are supported by another report (Nowak et al., 2004).

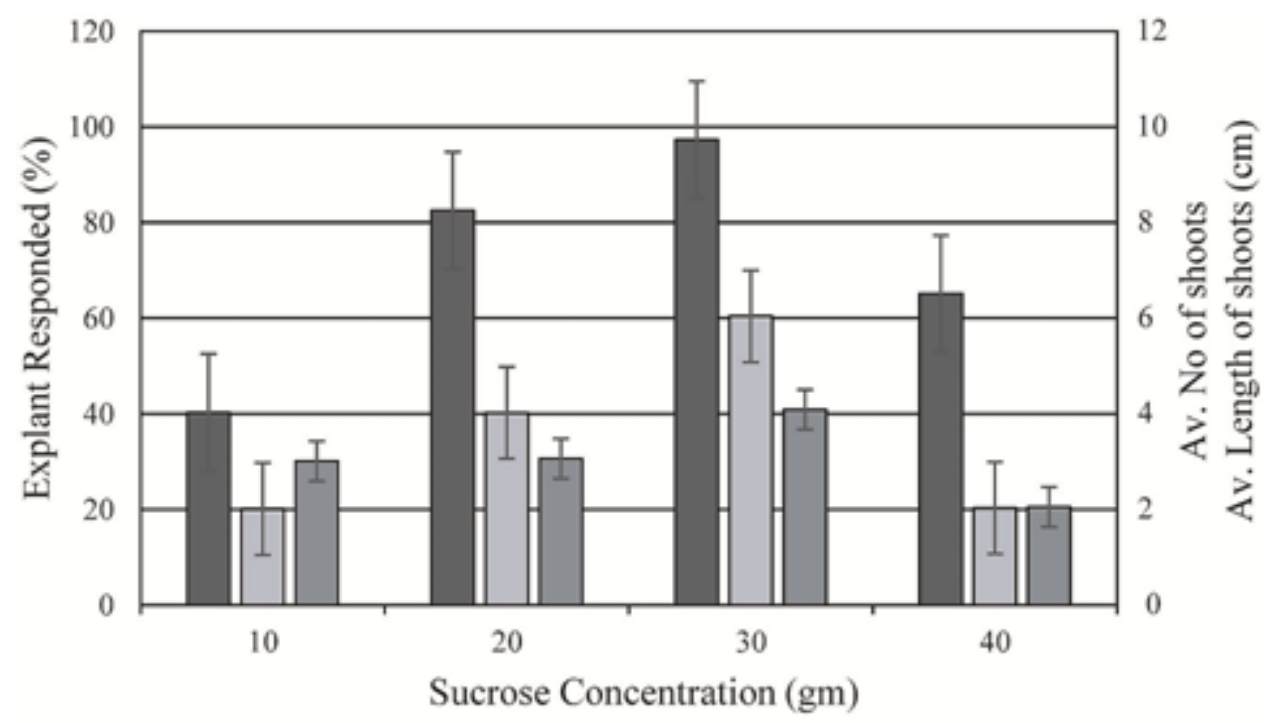

$\square$ Explant responded $\square$ Av. No of shoots $\square$ Av. Length of shoots $(\mathrm{cm})$

Figure 4. Effects of sucrose concentrations on axillary shoot proliferation on MS medium containing $4.0 \mu M$ BAP of Gynura porcambens.

Rooting frequency was enhanced considerably when either IBA, NAA or IAA at different concentrations were added to MS medium. IBA supplemented medium remarkably influenced the rate of root induction than NAA or IAA(Fig. 5). Among the different concentrations of IBA tested, highest frequency (95.0\%) with maximum number $4.3 \pm 0.3$ of roots per shoot and longest $6.2 \pm 0.1 \mathrm{~cm}$ roots having considerable lateral roots were obtained with $4.0 \mu \mathrm{M}$ IBA (Fig. 2D) whereas, $4.0 \mu \mathrm{M}$ NAA produced considerable root formation where highest frequency was 86.33 , average number of roots $3.4 \pm 0.1$, and average length of roots $4.1 \pm 0.2 \mathrm{~cm}$. On the other hand IAAwas found to be less effective than IBA or NAA regarding rooting of micro-shoots where the roots were thin in nature. Poor rooting was observed when micro-shoots (2-4 cm in length) were cultured on auxin free MS medium. In this study, IBA was proved to be best auxin as comparable to NAA or IAA with regard to all rooting parameters. There are many authors reported that IBA has been found suitable for rooting in many species like Gynura porcambens (Majumderet al., 2016), Acacia nilotica (Dhabhaiet al., 2010), Bauhinia variegata (Mathur and Mukunthakumar, 1996), Phellodendronamurense (Azad et. 
al., 2005, 2009), and Pterocarpus marsupium (Husain et al., 2008). After successful rooting of microshoots, attempts were taken to establish regenerated plantlets onto soil. Plantlets had been transferred to small plastic pots containing soil mix (garden soil: compost: sand, 2:1:1) and maintained under humid ex vitro condition in the growth room (Fig. $2 \mathrm{E}$ ). The in vitro derived plantlets acclimated better under ex vitro condition when they were maintained in growth room for 20 days before transferring them to outdoor condition (Fig. 2F). Finally, 95\% transplanted plantlets were survived and acclimated well under ex vitro condition after 25 days of transplantation.

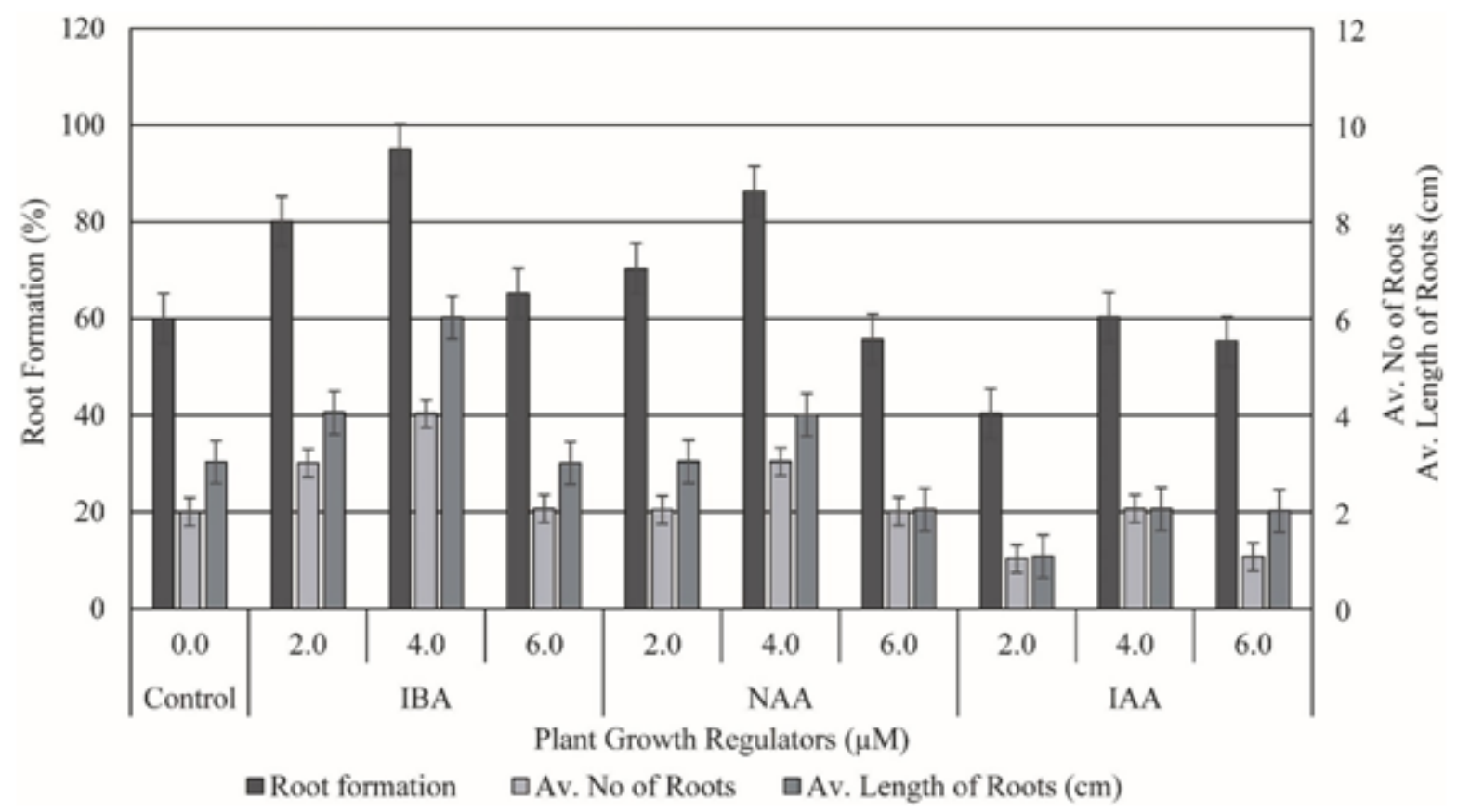

Figure 5. Effects of auxins on adventitious rooting on MS medium of in vitro derived micro-shoots of Gynura porcambens.

\section{CONCLUSiOnS}

Most of the populations of world are suffering from diabetes. They are using different types of drug for controlling diabetes. These drugs are very expensive especially human insulin. Poor people are unable to buy these drugs. So they are suffering from different disease due to the diabetes. Whereas we can easily control our diabetes by eating 4-6 leaves of G. procumbens daily. G. procumbens is commonly used for diabetes treatment in traditional medicine and its hypoglycemic effect has been reported in in vivo studies (Hamid et al., 2004; Algaririet al., 2014). By considering the medicinal value and antidiabetic properties of $G$. procumbens the present project has been undertaken for develop a suitable micropropagation protocol for the mass production of this plant species. Here, we developed an efficient protocol which can be used at a large scale for the clonal multiplication of this plant species using nodal segments as explants derived from the adult plants and will be followed by the optimized conditions for in vitro rooting and further transfer into the greenhouse. The described strategy demonstrates an efficient system of in vitro clonal propagation of Gynura porcambens via node and shoot tip explants, which could play a significant role in large scale plantlet production all around the year, as well as in wide plantation and in conservation of this plant's genetic resources.

\section{ACKNOWLEDGEMENT}

This work was finically supported by the Institute of Biological Sciences, Rajshahi University, Bangladesh (No. A-1214-5/52/RU/Life \& Earth-03/16-17/64). The authors also like to thank their colleagues from the Department of Botany, University of Rajshahi for their constant assistance and cooperation. 


\section{REFERENCES}

Abbas, H., Qaiser, M.,\&Naqvt, A. B. (2010). Rapid in vitro multiplication of Accaianiloticasubsp. hemisperica, a critically endangered endemic taxon. Pak. J. Bot. 42(6):4087-4093.

Abdullah, N., Hassan, N. H., Rahman, S. S. A., Ismail, H., Khalid, R.,\&Yahya, M. F. (2014): In vitro propagation of Phaleriamacrocarpa, God's Crown. J. Biotechnol. Pharma. Res. 5(2): 18-23.

Akowuah, G. A., Amirin, S., Mariam, A.,\&Aminah, I. (2001). Blood sugar lowering activity of Gynura procumbens leaf extracts. J. Trop. Med. Plant 2: 5-10.

Algariri, K., Atangwho I. J., Meng, K. Y., Asmawi, M. Z., Sadikun, A., \&Murugaiyah, V. (2014). Antihyperglycaemic and toxicological evaluations of extract and fractions of Gynura procumbens leaves. Trop. Life. Sci. Res.25: 75-93.

Alizah, Z.,\&Nurulaishah, Y. (2015). Multiple Shoot Regeneration from Nodal Explants of Gynura procumbens (Lour.) MerrAnnual Res. Rev. Biol. 6(2): 85-88.

Amin, M. N., Rahman,M. M.,\&Manik,M. S.(2003). In vitro clonal propagation of Paederiafoetida L. A medicinal plant of Bangladesh. Plant Tiss. Cult. 13: 117-123.

Azad, M. A. K. (2012). Plant regeneration through callus-derived protoplasts of PhellodendronamurenseRupr. BioTechnol: An Indian J. 6(10): 317-326.

Azad, M. A. K., Amin,M. N.\& Begum,F.(2003). Rapid clonal propagation of a medicinal plant AdhatodavasicaNees. using tissue culture technique. OnLine J. Biol. Sci.3 (2): 172-182.

Azad, M. A. K., Yokota, S.,Yahara,S., \&Yoshizawa,N.(2004). Effects of explant type and growth regulators on organogenesis in a medicinal tree, PhellodendronamurenseRupr. Asian J. Plant Sci. 3(4): 522-528.

Azad, M. A. K., Yokota,S., Ohkubo,T.,Andoh, Y.,Yahara,S.and Yoshizawa,N.(2005). In vitro regeneration of the medicinal woody plant PhellodendronamurenseRupr. through excised leaves. Plant Cell Tissue and Organ Cult.80(1): 43-50.

Azad, M. A. K., Yokota, S., Begum, F., \&Yoshizawa, N. (2009). Plant regeneration through somatic embryogenesis of a medicinal plant, PhellodendronamurenseRupr. In vitro Cell Dev Biol Plant. 45(4):441-449.

Azad. M. A.K., Yokota, S., Ohkubo, T., Andoh, Y., Yahara, S., \&Yoshizawa. N. (2005). In vitro regeneration of the medicinal woody plant PhellodendronamurenseRupr. through excised leaves. Plant Cell Tissue Organ Cult 80:43-50.

Begum, F., Amin,M. N.\&Azad,M. A. K.(2002) In vitro rapid clonal propagation of Ocimumbasilicum L. Plant Tissue Cult. 12(1): 27-35.

Casado, J. P., Navarro, M. C., Utrilla, M. P., Martinez, A.,\& Jimenez, J. (2002). Micropropagation of SantolinacanescensLagasca and in vitro volatiles production by shoot explants. Plant Cell Tissue Organ Cult. 69:147- 153.

Dhabhai, K., Sharma, M. M.,\&Batra, A. (2010). In vitro clonal propagation of Acacia nilotica (L.)-a nitrogen fixing tree. Researcher. 2(3):7-11.

Elinorovololona, R. N.,\& Martial, E. L. (2014). Effects of growth regulators 6-Benzylaminopurine and 2-Naphtalene Acetic Acid on the in vitro shoot multiplication from nodal segment of Medinillamandrakensis (Melastomataceae). Intl. J. Biochem. Biotechnol. 3 (1): 504-510.

Gamborg, O. L., Miller, R. A., \&Ojima, K., (1968) Nutrient requirements of suspension cultures of soybean root cells. Exp. Cell Res. 50: 151-158.

Hamid, M., Saufi, M., \&Nik, M. M. (2004). Study on antidiabetic properties of Gynura procumbensMerr, in 18 Seminar of the Malaysian Natural Products Society (Kota Kinabalu: Universiti Malaysia Sabah). 
Hegazi, G. A. E.,\&Gabr, M. F. (2010). Overcoming early shoot senescence of ColuteaistriaMiller propagated in vitro. J Am Sci. 6(12):1733-1738.

Husain, M. K., Anis, M.,\&Shahzad, A. (2008). In vitro propagation of a multipurpose leguminous tree (Pterocarpus marsupiumRoxb.) using nodal explants. Acta. Physiol. Plant. 30:353-359.

Hussain, T. M., Chandrasekhar, T., \&Gopal, G. R. (2007). High frequency shoot regeneration of SterculiaurensRoxb. an endangered tree species through cotyledonary node cultures. Afr. J. Biotech. 6(14):1643-1649.

Iskander, M. N., Song, Y., Coupar, I. M., \&Jiratchariyakul, W, (2004). Antiinflammatory screening of the medicinal plant Gynura procumbens. Plant Food Hum.Nutr. 57(3-4): 233-244.

Kaur, K., Verma, B., \&Kant, U. (1998). Plants obtained from the khair tree (Acacia catechuWilld.) using mature nodal explants.Plant Cell Rep. 17:421-429

Keng, L., Lim, S. Y., \& Pan, L. P. (2009). Micropropagation of Gynura procumbens (Lour.) Merr. an important medicinal plant. J. Medicinal Plants Res. 3(3):105-111.

Lam, S. K., Idris, A., Bakar, Z. A. A., \&Ismail, R. (1998). Gynura procumbens and blood pressure in the rat: Preliminary study. Asia Pac J Pharmacol. 13: S14-15.

Majumder, S., Biswas. A., \&Rahman, M. M. (2016): In vitro mass propagation of Gynura procumbens (lour.) Merr. - an important medicinal plant. Asian J. Natural \& Applied Sci. 5(3): 71-79.

Malik, S. K., Chaudhury, R.,\&Kalia, R. K. (2005). Rapid in vitro multiplication and conservation of Garcinia indica: A tropical medicinal tree species. Scientia Horticult.106:539-553.

Martin, K. P. (2003) Rapid in vitro multiplication and ex vitro rooting of RotulaaquaticaLour., a rare rhoeophytic woody medicinal plant. Plant Cell Rep. 21:415-420.

Mathur, J.,\&Mukunthakumar, S. (1996). Micropropagation of Bauhinia veriegata and Parkensoniaaculeata from nodal explants of mature trees. Plant Cell Tissue OrganCul. 28:169175.

Mei, C. L. (2005). Micropropagation of VitisthunbergiiSieb. et. Zucc., a medicinal herb, through high requency shoot tip culture. Scientia Horticult, 107: 64-69

Murashige, T.\& Skoog, F. (1962) A revised medium for rapid growth and bioassays with tobacco tissue cultures. Physiol. Plant. 15: 473-497.

Nilanthi, D.,\&Yang, Y. (2013) In vitro induction of octaploid from colchicine-treated tetraploid petiole explants of Purple Coneflower (Echinacea purpurea L.). Tropical Agril. Res.Extn.16.

Niranjan, M. H., Sudarshana, M. S.,\&Girisha, S. T. (2010). In vitro multiple shoot induction from excised shoot tips and nodal segment explants of - Lagerstroemia indica $(\mathrm{L})$ - A medicinal cum Ornamental Shrub. J. Biomed. Sci. Res.2(3):212-217.

Nowak, B., Miczynski,K., \&Hudy, L. (2004). Sugar uptake and utilization during adventitious bud differentiation on in vitro leaf explant of WegierkaZwykla plum (Prumusdomestica). Plant Cell Tissue Organ Cult. 76: 255-260.

Parvin, F., Islam, M. J., Naoshin, J., Habiba, K., Shaekh, M. P. E., Aminul, I. M., Rahman, M. H., \&Rahman, M. M. (2014). Efficient in vitro micropropagation of Gynura procambens- an important rate medicinal plant, throuth shoot tip and nodal segments. J. Res. Biol. 4(6): 14441450.

Rahman, M. M., Amin,M. N.,\&Ahmed,R.(2004). In vitro rapid regeneration from cotyledon explant of native olive (ElaeocarpusrobustusRoxb.). Asian J. Plant Sci. 3: 31-35. 
Rajeswari, V.,\&Paliwal, K. (2008). In vitro plant regeneration of red sanders (PterocarpussantalinusL.f.) from cotyledonary nodes. Ind. J. Biotech. 2:541-546.

Tiwari, K. N., Sharma, N. S., Tiwari, K.,\& Singh, B. D. (2000). Micropropagation of Centellaasiatica(L.), a valuable medicinal herb. Plant Cell Tissue Organ Cult.63(3): 179-185

Tiwari, S. K., Kashyap, M. K., Ujjaini, M. M.,\& Agrawal, A. P. (2002). In vitro propagation of LagerstromiaparvifloraRoxb. from adult tree. Ind. J. Exp. Biol. 40:212-215.

Xu, Z., Um, Y. C., Kim, C. H., Lu, G., Guo, D. P., Liu, H. L., Bah, A. A.\& Mao, A. (2008). Effect of plant growth regulators, temperature and sucrose on shoot proliferation from the stem disc of Chinese jiaotou (Allium chinense) and in vitrobulblet formation. Acta. Physiol. Plant. 30:521528.

Citation: M. A. Azad, M. N. Amin, "In Vitro Regeneration and Ex Vitro Establishment of an Antidiabetic Plant- Gynura procumbens (Lour.) Merr.", International Journal of Advanced Research in Botany, vol. 3, no. 4, p. 6-15, 2017. http://dx.doi.org/10.20431/2455-4316.0304002

Copyright: (C) 2017 Authors. This is an open-access article distributed under the terms of the Creative Commons Attribution License, which permits unrestricted use, distribution, and reproduction in any medium, provided the original author and source are credited. 